Journal of Engineering Sciences, Assiut University, Vol. 40, No 2, pp.343-352, March 2012

\title{
EFFECT OF EARTHQUAKE ON STEEL FRAMES WITH PARTIAL RIGID CONNECTION
}

\author{
MOHAMED A. A. EL-SHAER \\ Assistant Professor, Department of Civil Engineering, Higher \\ Technological Institute, $10^{\text {th }}$ of Ramadan City
}

(Received December 15, 2011 Accepted January 29, 2012)

The present study is aiming to evaluate the seismic performance of moment resisting steel frames with partial rigid connections considering elastoplastic behavior of girder to column connection under the effect of earthquake loadings. The frame performance prediction and evaluation procedure are mainly based on the nonlinear dynamic analysis considering both geometrical and material nonlinearities.

The current paper investigates the effects produced by some earthquake records on steel moment resisting frames considering both SDOF (SINGLE DEGREE OF FRADOM) system and MDOF (MULTI DEGREE OF FRADOM) system. Statistical analyses are performed to characterize the response of such frames by obtaining comparable results that allow the determination of the behaviour factor for each frame (Q-factor) which expresses the degree of damage for each frame.

The results summarized in terms of base shear-top displacement relationships considering different earthquake records and at P.G.A. (Peak Ground Acceleration) level 0.35G (0.35 from ground acceleration levels). Finally the values of the $Q$-factor for each frame and the comparison of such values with respect to the current seismic provisions were outlined.

KEYWORDS: Earthquake, Moment resisting frames, Girder to columnconnection, behavior factor.

\section{INTRODUCTION}

In 1997 studying the composite beams of steel structural for partial rigid connection between concrete and steel beam which due to monotonic load [1]. A column design curve only in steel structural for slender sections was established by applying a reduction factor, $\mathrm{Q}$, to the LRFD column design curve for monotonic load without effect of earthquake [2].

Similar to the Euro-Code3, the Egyptian Code based on the allowable stress design, ASD and LRFD accounts for local buckling of slender plate elements for steel frame by applying the effective width concept $[3,4]$.

Many design approaches have recently been proposed as a basic philosophy for designing steel structures. In general, the E/Q resistant design philosophy states that structures should be designed to resist low intensity earthquakes with no damage $[5,6]$ (structural elements and nonstructural element), medium intensity earthquakes with a minor damage level and high intensity earthquakes with a significant damage to both structural and non structural element and with out over all or partial collapse in order to avoid loss of life. For such a purpose, in order to resist destructive earthquakes, structures should be designed to give a significant dissipative energy during E/Q 
actions. Also, they shall be designed so that they can undergo inelastic deformations during earthquakes. In general, prediction of seismic response of a steel moment resisting frame is a problematic matter, due to not only the large number of factors that affect on its performance but also due to the basic complexity of its physical behavior. In addition, the lack of knowledge in interpreting the MRF (Moment Resisting Frames) characteristics and the variability of the nature of ground motions that may happen in the future, create a big importance in studying the behavior of such frames [7].

However, in the case of seismic loading, there have not been until recently any provisions that may judge the performance of these frames under the unexpected time histories of Earthquakes. Also, structural failures observed in the beam to column connections [8] have exposed the weakness of the prevalent design provisions and construction procedures for steel moment frames and showed the need for new methods for evaluation of the frame performance and design [9]. There are new European Researches Projects in Support of partially composite steel structure in the Eurocode 9 [10].

This paper presents a study for three different steel moment resisting steel frames in order to investigate the seismic behavior of such frames under the effect of Earthquake record at P.G.A equal, 0.35 G.

\section{STRESS STRAIN RELATIONSHIP FOR STEEL}

For simplicity, the uniaxial monotonic idealized stress-strain relationship for structural steel elements is considered to be bilinear curve as shown in Fig.1.

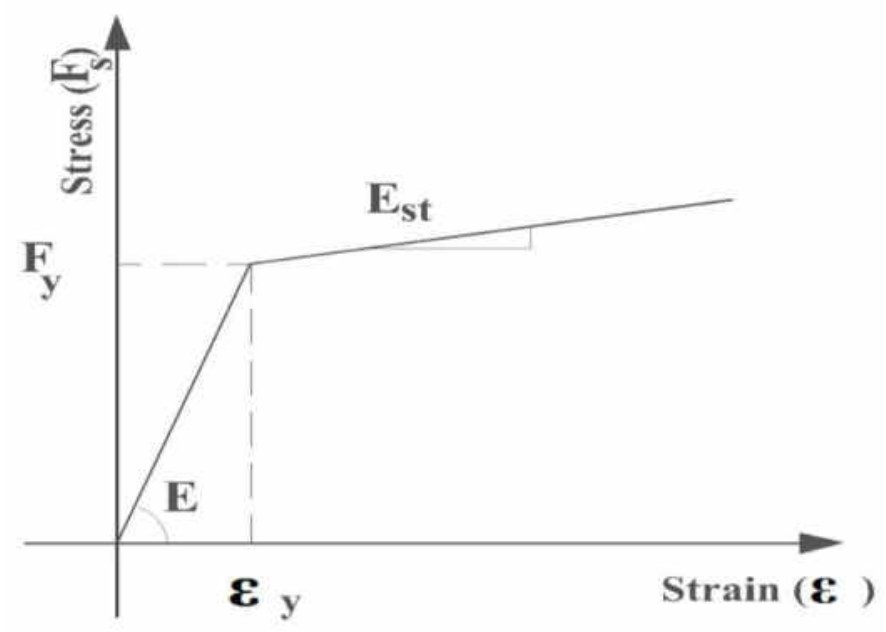

Fig. 1 Idealized Stress-strain curve for steel

While this is adequate for static design purposes, the use of nonlinear constitutive reversible relationship should be used for dynamic analysis.

Figure 2 shows the stress-strain relationship for idealized bilinear reversible constitutive model. The important features of a nonlinear constitutive model for steel structures are cyclic hardening softening and mean stress relaxation. 


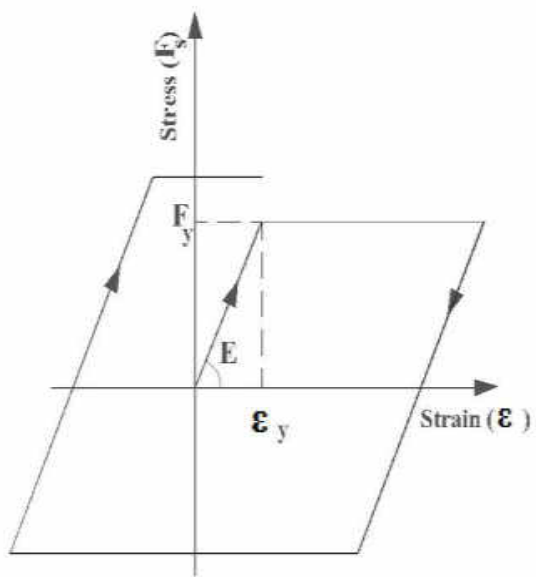

(a) Perfectly Plastic Cyclic Model

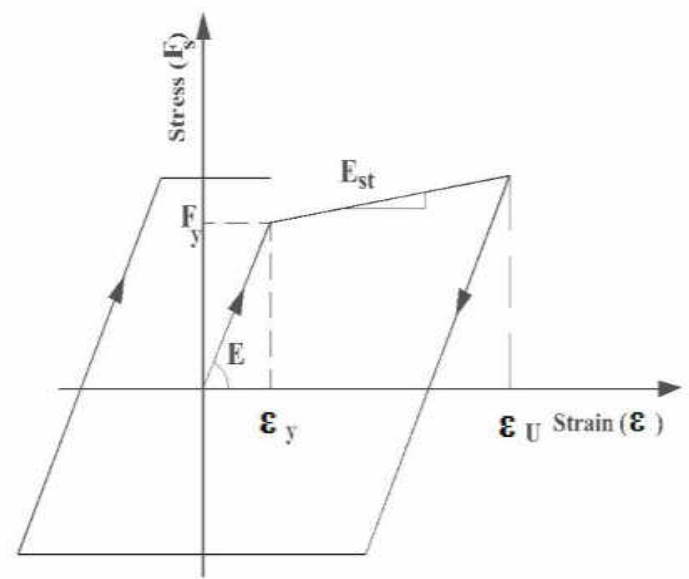

(b) Strain Hardening Cyclic Model

Fig. 2 Perfectly Plastic and Strain Hardening Cyclic Model

Where, $\mathrm{f}_{\mathrm{s}}$ is the steel stress; $\mathrm{f}_{\mathrm{y}}$ is the specified yield strength of steel; $\varepsilon_{\mathrm{s}}$ is the steel strain and $\varepsilon_{\mathrm{y}}$ is the steel yield strain.

\section{A- Stiffness}

Stiffness can be defined as the property used to quantify and control the deformation of an element or connection under the effect of a certain force. There are some parameters that affect the stiffness of steel element including local buckling of elements auch as overall buckling of the structural elements, lateral torsion buckling and $\mathbf{P}-\boldsymbol{\Delta}$ effect.

Figure 3 shows a relationship between load and displacement for a steel structural element subjected to monotonic increasing load. For design purposes, the real response may be approximated to an idealized bilinear relationship, where $\mathbf{F}_{\mathbf{y}}$ is defined as the yield load of the element. The slope of the idealized linear elastic response (first part of the curve) represents the elastic stiffness of the element $\left\{\mathbf{K}_{\mathbf{e}}=\mathbf{F}_{\mathbf{y}}\right\}$ $\left.\Delta_{\mathbf{y}}\right\}$.

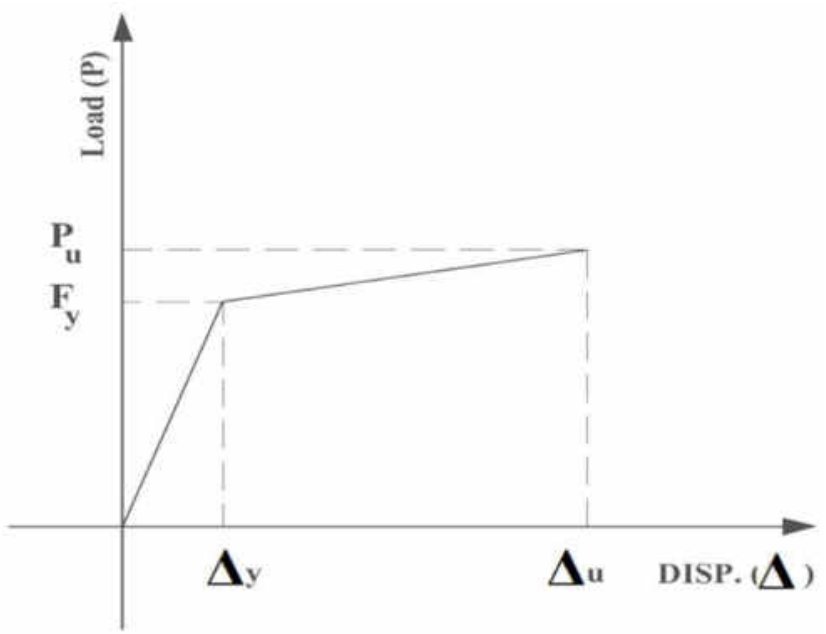

Fig. 3 Load-Displacement relationship for monotonic loading 
The slope of the idealized plastic response (second part of the curve) represents the hardening stiffness of the element $\left\{\mathrm{K}_{\mathrm{p}}=\left(\mathrm{P}_{\mathrm{u}}-\mathrm{P}_{\mathrm{y}}\right) / \boldsymbol{\Delta}_{\mathrm{u}}-\boldsymbol{\Delta}_{\mathrm{y}}\right\}$. Also, Fig. 4 shows the real idealized response for load displacement relationship under the effect of cyclic loading. Generally, under the effect of the cyclic loading, the structural elements stiffness will subject to degradation of their stiffness due to the fatigue phenomena.

\section{B- Drift Criteria}

The main definition for the structure drift is the lateral displacement of that structure due to vertical and horizontal loads.

Threre are two kinds of the structual drift that shoud be controlled within the effect of earthquake. These include inter-story dirift and overall drift.

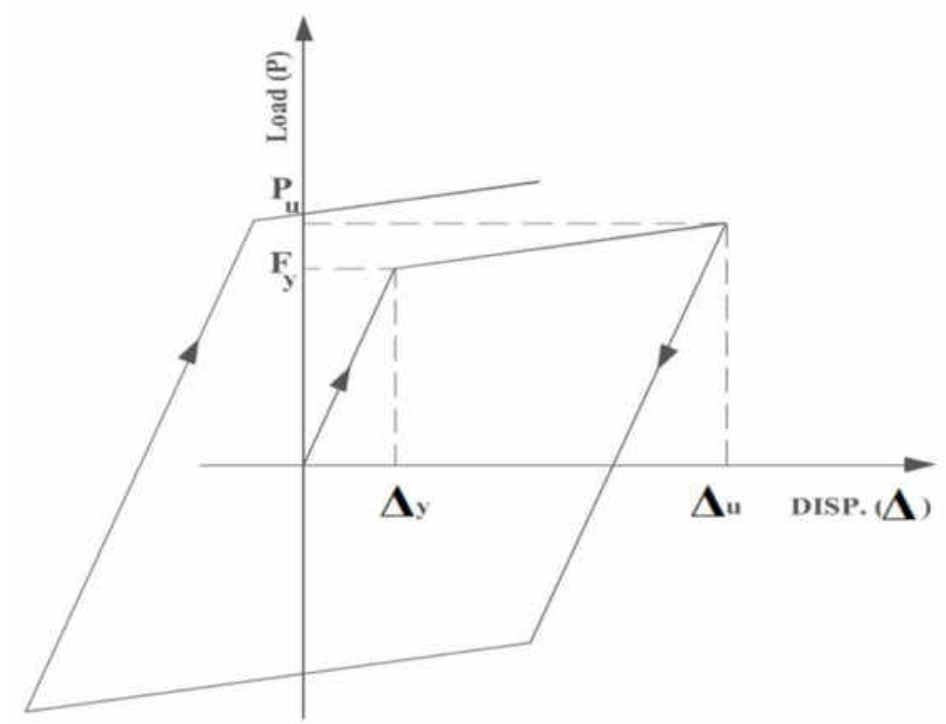

Fig. 4 Load-Displacement relationship for cyclic loading

\section{C- Response Spectra}

The response spectrum for a damped single degree of freedom system can be defined as a plot of the max. peak response of that structure at various frequencies or periods and damping ratios for a specific ground motion. For a given earthquake record and a given percentage of critical damping the spectrum graph shows related quantities such as acceleration, velocity and displacement for a complete range or spectrum of building period. Fig. 5 shows an acceleration response spectra for three records of earthquake[10,11,12].

\section{EVALUATION OF THE DUCTILITY FACTOR $(\mu)$}

In this paper the factor that was considered to express the damage of the frame due to E/Q loading is the global behavioral factor (Q-factor) which is based mainly on the ductility factor of the frame $(\underline{\mu})$. 


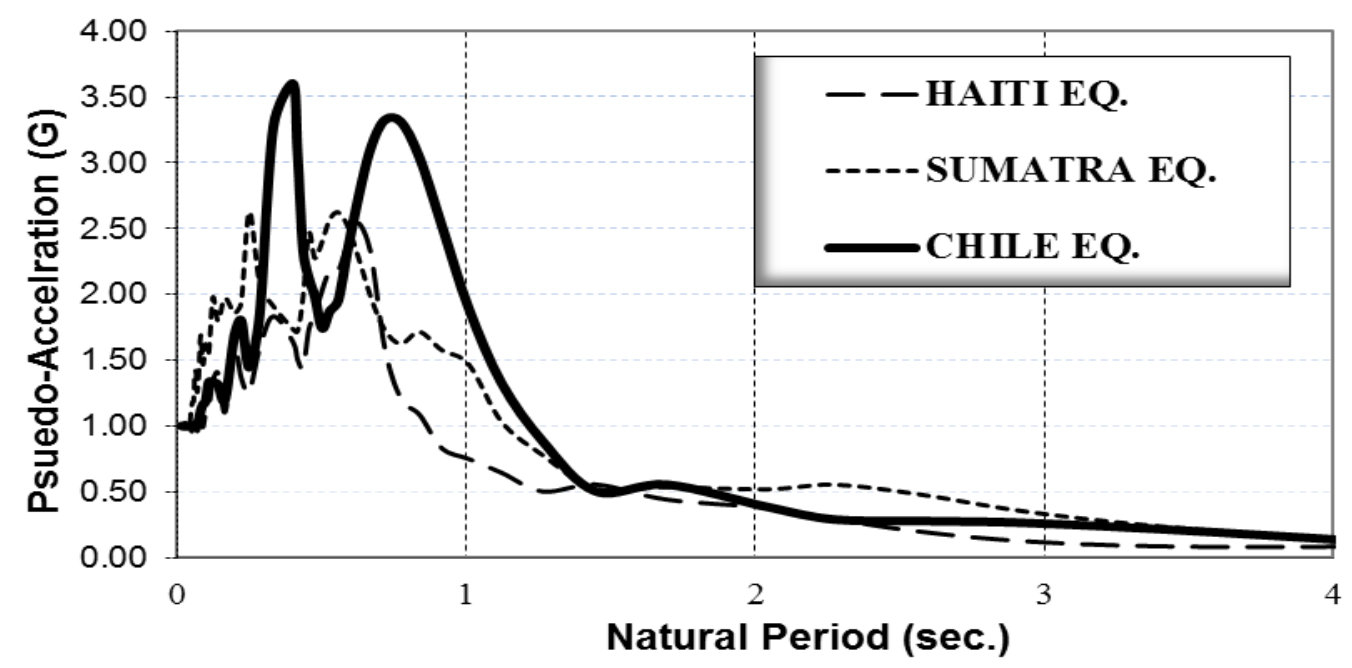

Fig. 5 Response spectra for earthquake records

The method of evaluation of the ductility factor is mainly based on the nonlinear dynamic analysis of the frame and from the analysis the relationship between both shear and top displacement is plotted. From this relationship the maximum loop is adopted to calculate the parameters of the ductility factor as shown in Fig. 6 from the figure the ductility factor can be given as follows:-

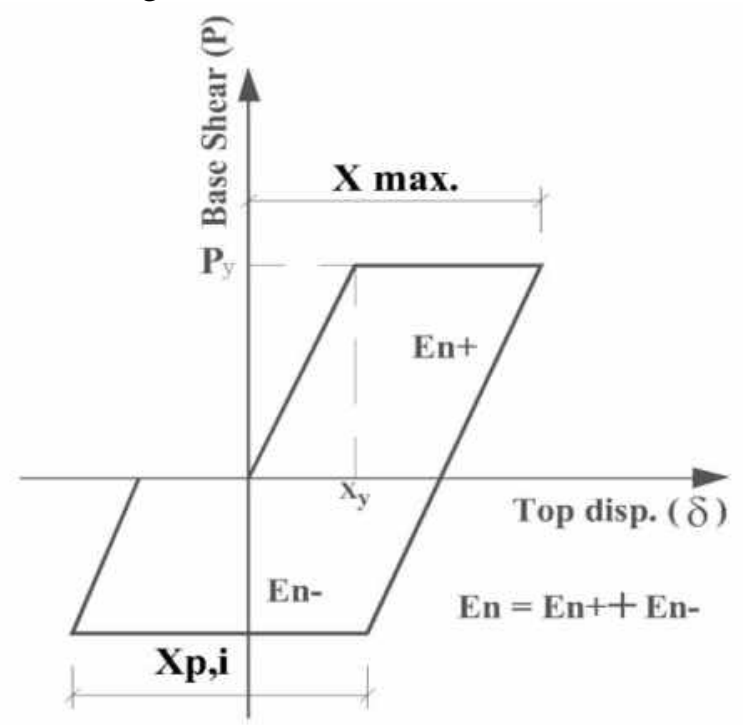

Fig. 6 Lateral drift- Base shear relationship (Max. excursion)

$$
\mu_{n}=\frac{E_{n}}{P_{y} \cdot X_{y}}+1
$$

Where,

$\mathrm{E}_{\mathrm{n}}=$ total max. hysteretic energy $=\mathrm{E}_{\mathrm{n}}^{+}+\mathrm{E}_{\mathrm{n}}^{-}$

$\mathrm{F}_{\mathrm{y}}$ and $\mathrm{X}_{\mathrm{y}}$ are as given by Fig. 3 
Also the Q-factor for moment resisting steel frame can be computed as given by Euro code 8 as: $\mathrm{Q}=5.0^{*} \mu \quad$ which expresses the elastic behaviour of the frame under the effect of seismic actions.

\section{DESCRIPTION OF ANALYZED FRAMES}

Three steel frames were designed to investigate the seismic response of moment resisting frames. These frames were shown in Fig. 7, in which the span length and interstory height were respectively, 5.0 and $3.3 \mathrm{~m}$ except for the ground floor in which the interstory height is $4.0 \mathrm{~m}$. Dead and live loads per unit length of beam are $2 \mathrm{t} / \mathrm{m}$ ' and $0,8 \mathrm{t} / \mathrm{m}$, respectively. The frames have been designed according to instructions provided by Eurocode8 and Eurocod3 [10] for dissipative structural behavior, by assuming the behavior factor proposed for high ductility class frames and adopter class one steel profiles. The masses of each floor have been evaluated based on the dead load only.

All frames have pined supports, critical damping ratio considered of 5\%, ground acceleration level was considered for all earthquake records of $0.35 \mathrm{G}$. Each frame made of mild steel with yield stress, fy= $2400 \mathrm{~kg} / \mathrm{cm} 2$, ultimate strength, $\mathrm{f}_{\mathrm{u}}=3600 \mathrm{~kg} / \mathrm{cm} 2$, strain hardening ratio, $\mathrm{C}=1 \%$, young's modulus, $\mathrm{E}=2100 \mathrm{t} / \mathrm{cm} 2$, and passion's ratio $=0.3$

The nonlinear spring element was chosen to represent the beam to column connection in which the $\mathrm{M}-\Phi$ curve data, representing the rotational stiffness for the end plate connection were taken [9].

The analysis methodology for evaluating the seismic response for MRF is the nonlinear dynamic analysis considering both geometric and material nonlinearities. The analyses have been conducted using the software program COSMOS/M in which the acceleration time histories for different Earthquake records were used.

\section{Beam Column Element Model}

It is known that, a two dimensional beam column element has three modes of deformation (axial deformation, flexural rotation at both ends). In program Cosmos/M the element used to represent the beams and column, is Beam 3D element which has the following characteristics:

a- Two-node line element,

b- Each node has 6 degree of freedom,

c- Shape of element section used is symmetric section,

d- Material nonlinearity is modeled using the Von-Misses elastoplastic model with kinematic hardening, and

e- Geometric nonlinearity is considered using large displacement formulation.

\section{Earthquake Records}

Three different earthquakes have been chosen to study the dynamic response of the considered frames. The chosen ground records include Chile EQ., 2010, Sumatra EQ., 2010, and Haiti EQ., 2010 [11,12,13]. Fig5 shows the response spectra for these records scaled to $1.0 \mathrm{G}$. Table 1 shows the characteristics of the three chosen earthquake records. 

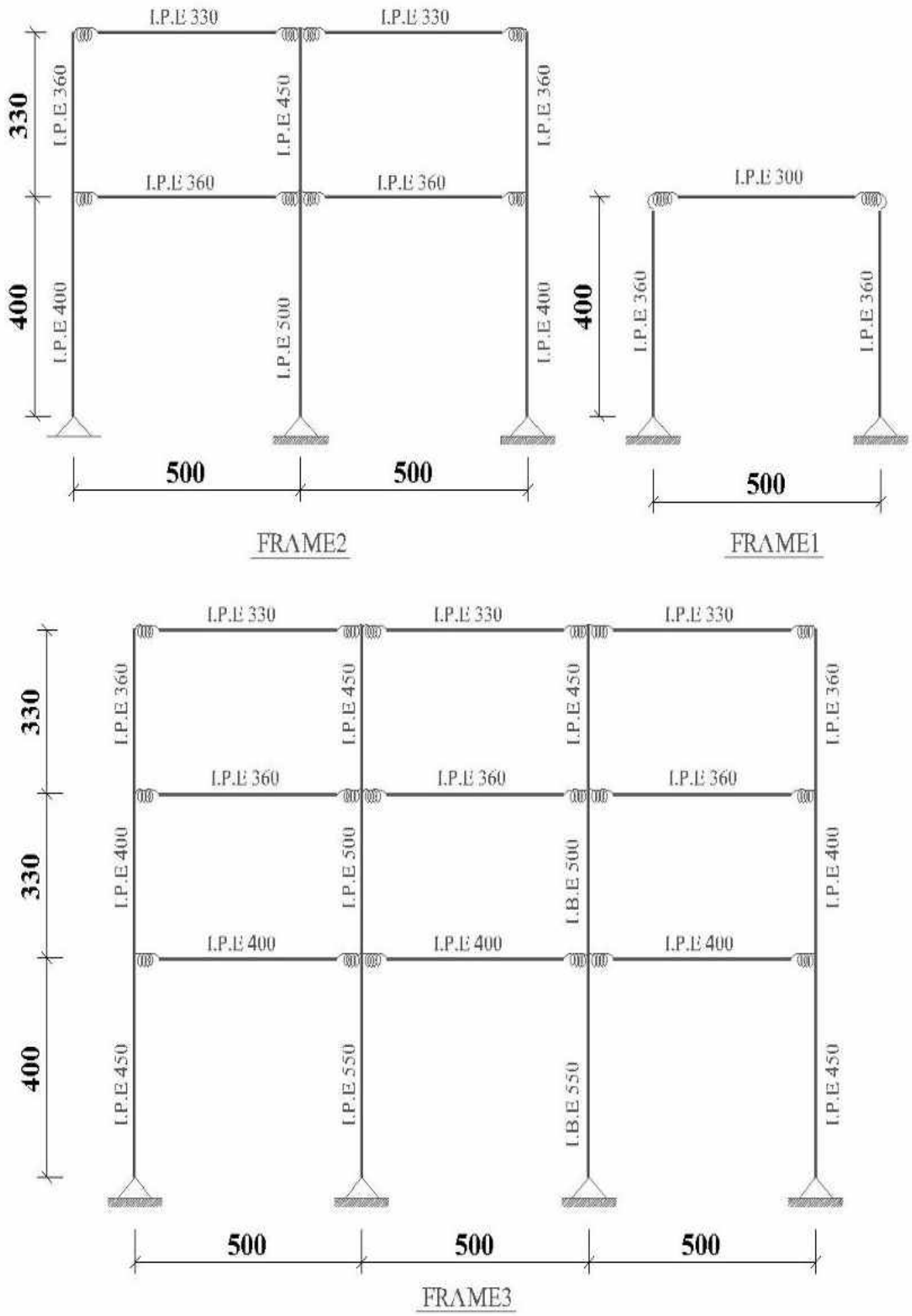

Fig. 7 One, two, and three-story frames 
Table 1 Summary of the ground motions characteristics

\begin{tabular}{|c|c|c|c|c|}
\hline $\begin{array}{c}\text { Property } \\
\text { Earthquake }\end{array}$ & $\begin{array}{c}\text { P.G.A } \\
\left(\mathbf{c m} / \mathbf{s e c}^{\mathbf{2}}\right)\end{array}$ & $\begin{array}{c}\text { P.G.V } \\
(\mathbf{c m} / \mathbf{s e c})\end{array}$ & $\begin{array}{c}\text { Duration of } \\
\text { strong mot. }\end{array}$ & $\begin{array}{c}\text { Time of P.G.A } \\
\text { (sec.) }\end{array}$ \\
\hline HAITI & 375.87 & 15.07 & 4.68 & 2.35 \\
\hline SUMATRA & 518.06 & 42.90 & 3.80 & 6.97 \\
\hline CHILE & 636.02 & 106.92 & 6.05 & 4.77 \\
\hline
\end{tabular}

\section{NUMIRICAL RESULTS}

As it was described in the previous section, the parameter which will be used for assessing the damage of the steel moment resisting frame is the behavioral factor for the frame which will be computed from the bigger loop of the base shear-top displacement hystertic behavior of the frame. Figures 8 to 10 show the base shear-top displacement relation ships for the analyzed frames considering different $E / Q$ records and at P.G.A $=0.35 \mathrm{G}$. Table 2 show the values of the $\mathrm{Q}$-factor for the analyzed frames and considering different E/Q records (three earthquake records) [11,12.13] . It is noted from the analysis of the results that the values of overall behavior factor are more conservative than those given by Eurocode 8 or UBC, 1997[10].

Table 2 Values of the Q-factor for the studied frames at P.G.A., 0.35G

\begin{tabular}{|c|c|c|c|}
\hline $\begin{array}{c}\text { Frame } \\
\text { No. }\end{array}$ & $\begin{array}{c}\text { CHILE } \\
\mathbf{2 0 1 0}\end{array}$ & SUMATRA 2010 & $\begin{array}{c}\text { HAITI } \\
\mathbf{2 0 1 0}\end{array}$ \\
\hline 1 & 3.380 & 2.871 & 4.343 \\
\hline 2 & 4.054 & 3.132 & 4.859 \\
\hline 3 & 4.217 & 3.260 & 5.091 \\
\hline
\end{tabular}

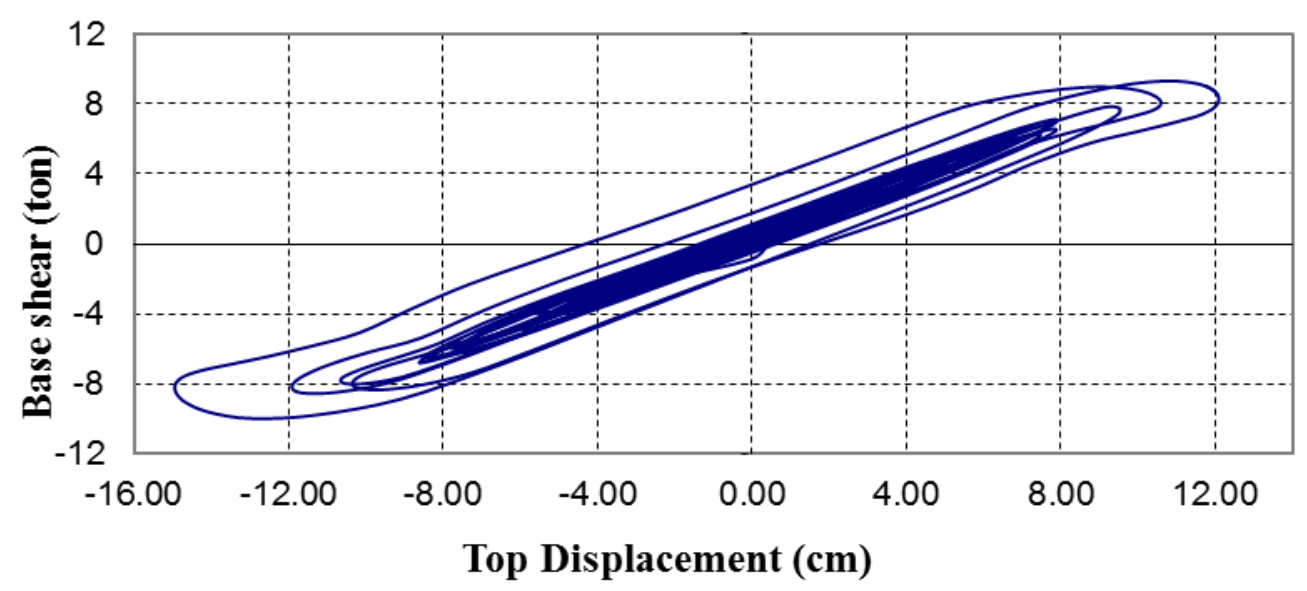

Fig. 8 Lateral drift-base shear relationship for the frame 1, Considering SUMATRA EQ. at P.G.A, 0.35G 


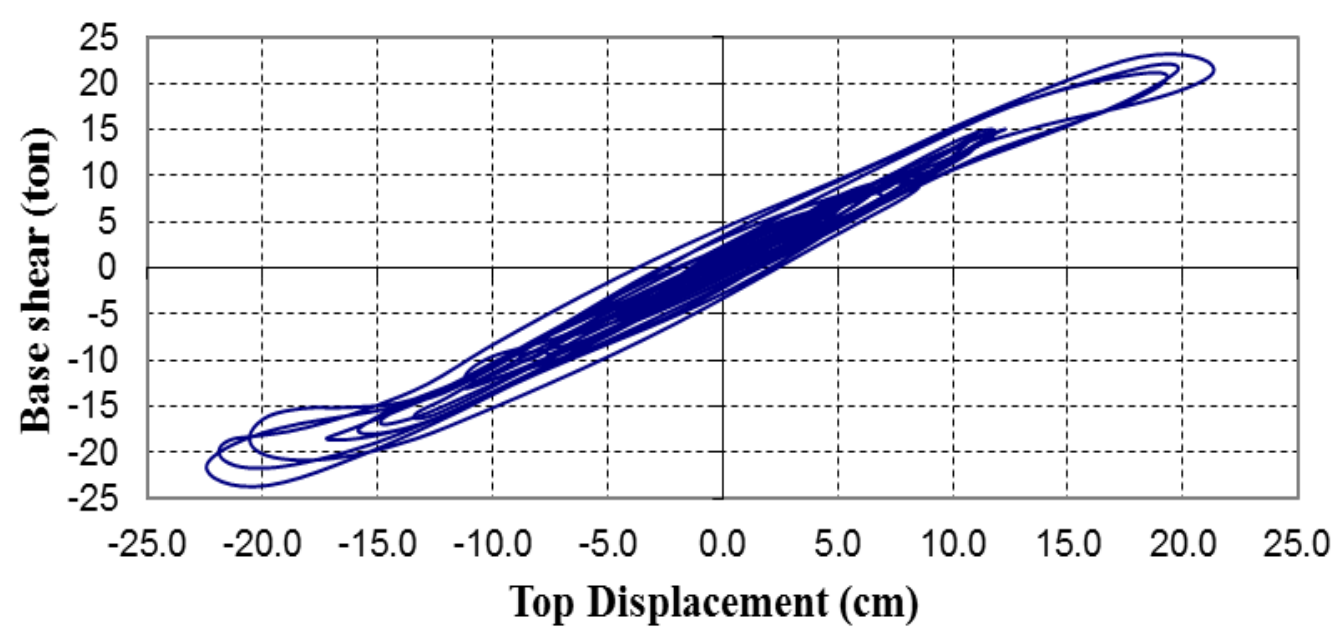

Fig. 9 Lateral drift-base shear relationship for the frame 2

Considering SUMATRA EQ. at P.G.A, 0.35G

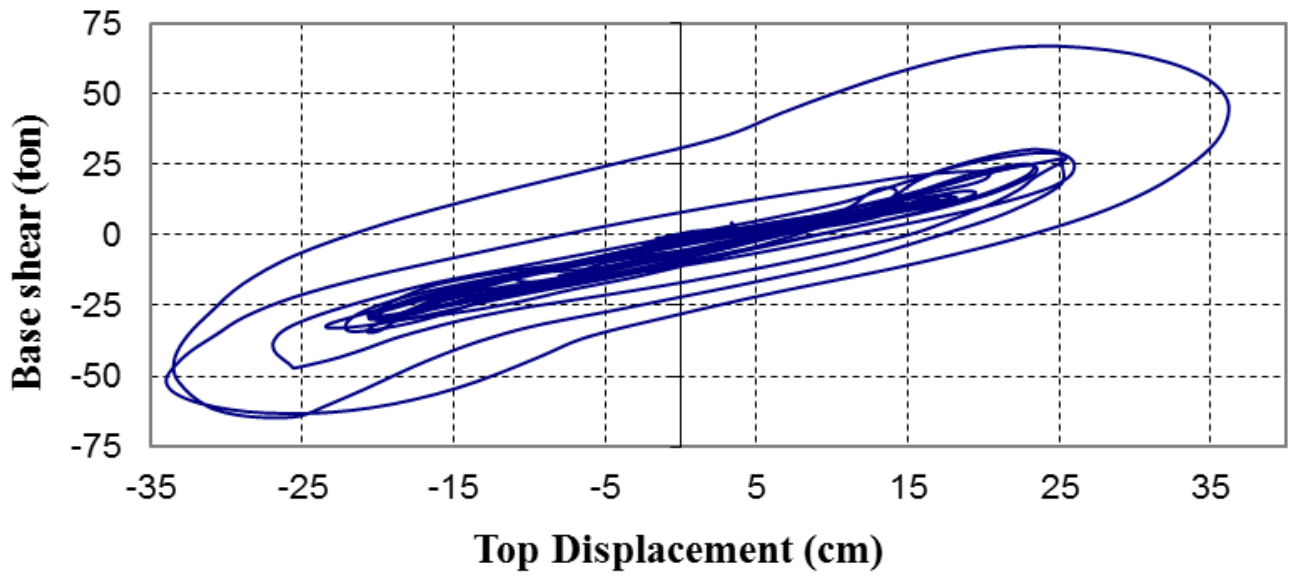

Fig. 10 Lateral drift-base shear relationship for the frame 3

Considering SUMATRA EQ. at P.G.A, 0.35G

\section{CONCLUSIONS}

This paper presents the results of extensive deterministic analysis performed on both SDOF and MDOF systems of moment resisting steel frames under repeated E/Q ground motions. The analysis demonstrated that the reputation of seismic events at short time may lead to damage of the frames which was assumed when the maximum inerstory drift reaches to $4 \%$ of the story height. From the analyses of the results the following conclusions can be summarized:-

1- $\quad$ Some acceleration ground motions cause more inelastic deformations than other for the same frame and at the same P.G.A level which indicates that damage parameters (as behaviour factor) can not be accurately specified as recommended by different provisions.

2- The global performance of the steel MRF is strongly depending on the inelastic behaviour of its beam to column connections. 
3- $\quad$ The behaviour factor for SDOF system is lower than that of MDOF system.

4- The behaviour factor values calculated are near to those proposed by different seismic codes.

\section{REFERENCES}

1- EL-SHAER M. A. A. "ANALYSIS OF COMPOSITE GIRDERS" ph. D. thesis, Ain Shams University, Cairo, Egypt (1997).

2- El-SHAER M. A. " Design of Steel Column Using LRFD Meth", Life Science Journal,. 2011; 8(4): 205-220] (ISSN: 1097-8135). http://www.lifesciencesite.com.

3- Egyptian Code of practice for Steel Construction and Bridges (Allowable Stress Design), Code no. Ecp (205), ${ }^{\text {st }}$ Edition 2001, Edition 2008.

4- Egyptian Code of practice for Steel Construction (load and Resistance) factor Design (LRFD) (205) Ministerial Decree No. 359-2007 First Edition 2008.

5- American Institute of steel Construction, INC. "Seismic Provisions for Structural Steel Building", AISC, April, 2010.

6- Mazzolani, F.M. and Piluso, V., "Theory and Design of Seismic Resistant Steel Frames", E\& FN SPON, London, 2009

7- Bonev, Z. and Hristov, H., "Behavior Factor Evaluation Based on SDOF System Presentation and Energy Approach", Journal of Earthquake Engineering and structural Dynamics, Vol. 30, January, 2011.

8- Fajfar, P., "Structural Analysis in Earthquake Engineering- A Breakthrough of Simplified Non-Linear Methods", $12^{\text {th }}$ European Conference on earthquake engineering, 2011.

9- AISC Specification "steel construction manual" American Institute of steel construction, Eighth edition, (2004).

10- Pinto, A. V., "Introduction to the European Research Projects in Support of Eurocode 9", $11^{\text {th }}$ European Conference on earthquake engineering 1998, Balkema, Rotrdam.

11- CHILE earthquake, Location (MAULE), 27 February 2010, Magnitude 8.8

12- SUMATRA earthquake, Location (INDONESIA), 25 October 2010, Magnitude-7.7

13- HAITI earthquake, Location (HAITI) 12 JANUARY 2010, Magnitude 7.0

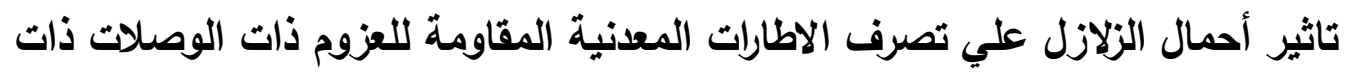
الجساءة المتوسطة.

هذة الدراسة نقدم تقييم نظري لتصرفات الاطارات المعنية الدقاومة للعزوم تحت تاثير أحمال الزلازل. وقد تم

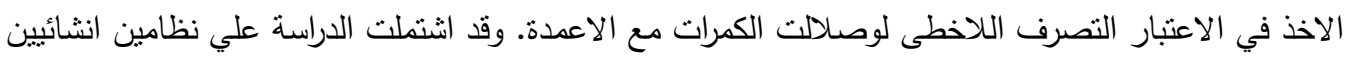

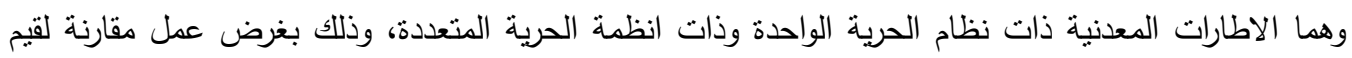

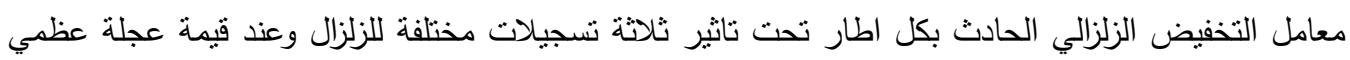
0.35G

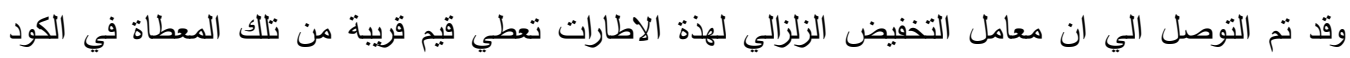

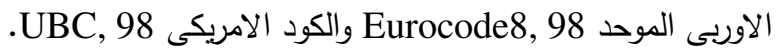

